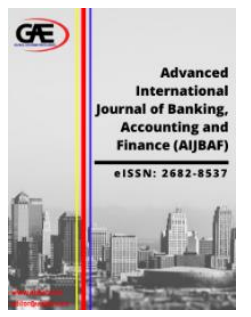

\author{
ADVANCED INTERNATIONAL JOURNAL OF \\ BANKING, ACCOUNTING AND FINANCE \\ (AIJBAF) \\ www.aijbaf.com
}

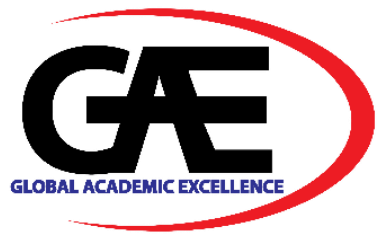

\title{
BANK LENDING BEHAVIOR: EVIDENCE FROM MALAYSIAN DUAL BANKING SYSTEM
}

\author{
Salwani Affandi ${ }^{1 *}$, Anis Izzati Ja' afar ${ }^{2}$, Fathiyah Ismail ${ }^{3}$, Nabilah Abdul Shukur ${ }^{4}$ \\ 1 Faculty of Business and Management, Universiti Teknologi MARA Cawangan Terengganu, Malaysia \\ Email: salwaniaffandi@uitm.edu.my \\ 2 Department of Operation, Bjak.com Selangor, Malaysia \\ Email: anisizzatijaafar7@gmail.com \\ 3 Faculty of Business and Management, Universiti Teknologi MARA Cawangan Terengganu, Malaysia \\ Email: fathi260@uitm.edu.my \\ 4 Faculty of Business and Management, Universiti Teknologi MARA Cawangan Negeri Sembilan, Malaysia \\ Email: nabilah@uitm.edu.my \\ * Corresponding Author
}

\section{Article Info:}

\section{Article history:}

Received date: 25.08 .2021

Revised date: 01.09.2021

Accepted date: 12.09.2021

Published date: 15.09 .2021

\section{To cite this document:}

Affandi, S., Ja'afar, A. I., Ismail, F., \& Shukur, N. A. (2021). Bank Lending Behavior: Evidence From Malaysian Dual Banking System. Advanced International Journal of Banking, Accounting, and Finance, 3 (8), 6575.

DOI: $10.35631 /$ AIJBAF.38006.

This work is licensed under $\mathrm{CC}$ BY 4.0

\begin{abstract}
:
This study investigates the internal and external factors that influence bank lending behaviors in Malaysian's dual banking system. The final regression of 24 commercial and 15 Islamic banks using the pooled ordinary least square (POLS) method revealed that the size of the bank proxies by the logarithm of total assets as the most significant factor influencing bank lending behavior in Malaysia from 2010 to 2018. This suggests that larger banks are more diversified and have a larger pool of funds to be loaned out. Because banks rely on deposits to issue loans, the deposits received by the bank have a substantial impact on bank lending. The greater the number of deposits obtained; the more bank lending activities will occur. The data also demonstrated that commercial and Islamic bank lending behavior in Malaysia is strongly connected with deposit volume (DEPO), GDP, and bank size (SIZE).
\end{abstract}

\section{Keywords:}

Bank Lending; Commercial And Islamic Banks; Bank Size; Total Deposits; POLS 


\section{Introduction}

The commercial bank's banking business relies heavily on lending activities. This is because loans and advances account for 61.24 percent of a commercial bank's asset portfolio (BNM, 2019). In addition, lending activities are one of the key sources of income for commercial banks in Malaysia, with interest income contributing for over 70 percent of operational income (BNM, 2014). This demonstrates that bank lending is critical to the Malaysian economy's vitality. Banks rely on interest margins and the number of deposits and loans they receive to fund their overheads and operating costs. While commercial banks rely heavily on loans to generate greater profit through interest rates, Islamic banks must follow Islamic standards and use loan-financing solutions that do not charge interest rates and must adhere to Shariah laws (Setyowati, 2019). Nonetheless, both banks play a significant role in the financial system as a bridge between the deficit and surplus units.

Commercial banks receive deposits, but Islamic banks employ the same transaction known as wadiah (safe-custody) from customers who have excess funds while also using the funds to grant loans to the financial market's deficit units. From 2007 to 2019, total loans and advances disbursed by commercial and Islamic banks in Malaysia increased year on year. This implies that commercial banks play a substantial role in financing Malaysia's economic operations. Recent issues with Malaysian commercial and Islamic banks, however, include poor credit quality and a significant number of problematic loans. According to the monthly highlights and data Bank Negara Malaysia website, the number of non-performing loans has continued to rise, especially from 2013 to 2018. As a result, the study's goal is to look at the relationship between many internal bank characteristics as well as economic indicators and lending activity among Malaysian commercial and Islamic banks.

A few research have been conducted to determine the factors that influence bank lending in various countries throughout the world. Abdul Adzis (2014) investigated the factors that influence commercial bank lending in Malaysia, as well as the impact of macroprudential regulatory measures enacted in 2010 . He stated that bank size and deposit volume have a substantial impact on commercial bank lending in Malaysia. On the other hand, Vo (2018), who focused on the rising market of Vietnam, found that bank size and operating costs had the greatest impact on bank lending in Vietnam. Prior to that, Ladime (2013) used the GMMSystem estimator to study bank lending in Ghana and found that bank size, central bank lending rate, exchange rate, and capital structure are the most relevant factors in bank lending.

Although several studies have been done on the determinants of bank lending around the world, there has been minimal research done in Malaysia on the determinants of bank lending that includes both Islamic and commercial banks. Furthermore, the prior studies' inconsistent results could be attributable to diverse techniques, datasets, time periods of investigation, and economic backgrounds. As a result, we are encouraged to do further research and statistically demonstrate what is the most important elements impacting bank lending across Malaysian commercial and Islamic banks are. 


\section{Literature Review}

\section{Bank Lending}

The term "lending" refers to a situation in which a bank provides a borrower with a credit facility in advance for a set length of time. Banks primarily provide advances for short-term reasons, such as the purchase of traded items and the payment of other short-term trading responsibilities. (Ergungor, 2011). Previous researchers used simple accounting measures such as total loans and advances of banks for measuring bank lending. (Abdul Adzis et al, 2018; Ladime, 2013; Ayieyo, 2016; Olumuyiwa, 2012). Meanwhile, Rabab'ah (2015) and Mansour (2017) quantified bank lending using the proportion of credit facilities to total assets (BC/TA).

Rabab'ah (2015) and Mansour (2017), on the other hand, employed the natural logarithm of net loans and advances in their research. Total annual gross loans and advances made by commercial banks to both the public and private sectors, according to Malede (2014), Moussa (2016), Abdul Karim et al (2010), and Matousek \& Solomon (2018). (Mukhanyi, 2016). Apart from that, Tabila, (2015) and Qudah (2017) have adapted loan to total assets, total business loan (Chernykh \& Theodossiou, 2011), Islamic banking credit facilities (Zulkhibri, 2018), credit risk (Waemustafa \& Sukri, 2015), and finally, the growth rate of bank loan (Vo, 2018).

\section{Bank Size}

The total value of a bank's assets determines its size (Amidu, 2014). Bank size is used to assess a bank's ability to lend money since large banks may benefit from economies of scale, with cheaper production and information costs, hence facilitating bank lending indirectly (Chernykh \& Theodossiou, 2011). The bank size is determined using logarithms value of total assets, according to Amidu (2014), Costant \& Ngomsi (2012), Chernykh \& Theodossiou (2011). Costant and Ngomsi (2012) looked at long-term bank loans in the Central African Economic and Monetary Community (CEMAC) by expressing bank size as a log of bank assets and discovered that bank size has a favorable impact on bank lending. In short, the larger the bank, the more diversified it will be, the more capable it will be to resist potential credit risks and, as a result, dedicate a higher percentage of its assets to business loans. Similarly, Rabab'ah (2015) examined a sample of 10 Jordanian commercial banks from 2005 to 2013 to conclude that bank size is the most important factor in determining a bank's willingness to lend, with the larger the bank, the higher the percentage of credit facilities provided. Mansour (2017) discovered that bank size has a significant impact on bank loan supply in another study in Jordan. This is in line with Chernykh and Theodossiou's (2011) study, which looked at the factors of banks' tendency to provide long-term loans in an emerging market context using a sample of Russian banks and found that bank size has a favorable impact on bank lending.

The reason for that would be because larger banks with better capital tend to lend more longterm credit to businesses than smaller banks with less capital. Abdul Adzis (2018) conducted his research in Malaysia and investigated the drivers of commercial bank lending using a sample of 27 banks from 2005 to 2014. The results suggests that in Malaysia, bank size had a favorable link with bank lending. This is because larger banks are more diversified, have greater pools of cash available, have access to larger and more creditworthy corporate clients, and have more resources to create advanced credit risk management and evaluation systems. Despite Abdul Adzis (2018), Vo (2018) evaluated bank lending behavior using a sample of Vietnamese banks and found that bank size has a negative relationship with lending activity. Copyright $\odot$ GLOBAL ACADEMIC EXCELLENCE (M) SDN BHD - All rights reserved 
Volume 3 Issue 8 (September 2021) PP. 65-75 DOI 10.35631/AIJBAF.38006

The reason for this is because larger banks give out fewer loans than smaller banks. The results were in line with those of Qudah (2017) and Ayieyo (2016), who found that small banks use riskier small business loan underwriting processes than larger banks, which ultimately determine the amount of credit available to the general population (Cole et al., 2004).

\section{Volume of Deposits}

Bank deposits refer to money placed into a banking institution for safekeeping. Bank deposits are made into deposit accounts such as savings, current, and money market accounts at a financial institution. The term "deposit" refers to the bank's liability to the depositor rather than the actual monies placed. (Ayieyo,2016). The volume of a deposit can be measured in a variety of ways. The total deposits to total assets ratio, as in prior research, was used to measure the proportion of deposits received versus the quantity of assets held by the bank. (Qudah, 2017; Moussa, 2016; Mansour, 2017; Rabab'ah, 2015, Abdul Adzis, 2018), the ratio of liquid assets to customer deposits and short-term borrowed money (Tabilla, 2015). (Mukhanyi, 2016; Malede, 2014) and, finally, deposit volume. As a result, deposit volume is an essential aspect that might influence the amount of loans given to a customer.

An increase in this ratio implies that there is more money in the bank, signaling that the bank has more lending capacity. Abdul Adzis (2018) found a positive and significant association between commercial bank lending and bank specific and macroeconomic factors in Malaysia, using a sample of 27 banks and covering the years 2005 to 2014. As a result, the greater the ability of commercial banks to draw more deposits from their customers, the greater their power to grant loans to the public. The findings are congruent with Mukhanyi's (2016) study of lending behavior among Kenyan commercial banks, which had the particular goal of examining the impact of bank-specific characteristics and external factors on lending behavior. The author argued that this is because a bank's ability to lend more money to its customers increases as its deposit grows.

\section{Inflation}

The annual change in the consumer price index is used by Rabab'ah (2015) and Mansour (2017) to estimate inflation. The inflation rate had a negative impact on the rate of growth in credit, according to Sharma and Gounder (2012), who studied changes in bank credit to the private sector across six economies in the South Pacific. This is because the growth in the volume of credit may be due to high rates of inflation rather than an increase in the real value of the facilities granted. Sarath \& Pham (2015), who investigated bank lending behaviour in Vietnam, agreed with the theoretical model's conclusion that banks must consider the predicted cost of a liquidity shortfall and, as a result, maintain an optimal loan-to-total-assets ratio.

According to Vo (2018), inflation has a detrimental impact on bank lending in Vietnam. This is because, in a high-inflationary economy, Vietnamese banks are likely to support the government's approach to inflation control by restricting their lending activity. In contrast, a study conducted by Qudah (2017) found that inflation has a favorable impact on bank lending. It is concluded as banks keep providing additional loans without being affected by inflation rate in Jordan. The positive association can be explained by the fact that when the rate of inflation rises, so does the demand for loans. This contributes to a rise in prices, which leads to an increase in bank interest as a result of the rise in prices. Furthermore, Moussa (2016) examined elements that may drive commercial bank lending in Jordan from 2010 to 2016 and discovered that inflation has a positive association with bank lending. As he concluded in his Copyright $\odot$ GLOBAL ACADEMIC EXCELLENCE (M) SDN BHD - All rights reserved 
Volume 3 Issue 8 (September 2021) PP. 65-75 DOI 10.35631/AIJBAF.38006

study, the results show that broad money, inflation, and GDP growth all tend to increase credit and allowances.

\section{Gross Domestic Product (GDP)}

Prior studies (Moussa, 2016; Amidu, 2014; Costant \& Ngomsi, 2012; Rabab'ah, 2015) used the annual percentage change in the gross domestic product at constant prices (GDP) as a proxy to analyze the relationship between the economic condition and commercial bank lending. Abdul Adzis (2018) discovered that GDP has a positive link with bank lending behaviour after studying the lending behaviour of 26 commercial banks in Malaysia.

When the economy expands, so does the demand for loans from the general public. As a result, banks will have more opportunity to provide loans to the public at large, resulting in a rise in bank lending. Furthermore, Olweny (2017), Mansour (2017), and Vo (2018) all reported the same findings for GDP, namely that there is a positive association between GDP and bank lending, implying that increased economic growth is linked to increased economic activity. Tabila (2015) and Moussa (2016), on the other hand, found that the GDP had a negative impact on bank lending in South Africa and Tunisia in a study done for South African and Tunisian banks.

\section{Data and Methodology}

We use data from Eikon Thompson Reuters and a World Bank unbalanced panel of 39 banks from 2010 to 2018 to evaluate the connection between the independent factors and bank lending. The initial sample consists of 24 commercial banks and 15 Islamic banks with comprehensive raw data for the study's time span. For this objective, the correlation coefficient was examined, and the data was analyzed with the Stata 14 software. Table 1 lists the variables used in this study as well as the measurements for each variable:

Table 1: Variables Used and Measurements

\begin{tabular}{|c|c|c|}
\hline Variable (Symbol) & Data Description & Literature followed \\
\hline Bank Lending (TLA) & $\begin{array}{l}\text { Total Loan and Advances/ } \\
\text { Total Asset }\end{array}$ & $\begin{array}{l}\text { Abdul Adzis et al, } 2018 \text {; } \\
\text { Ladime 2013; Ayieyo, } 2016 \text {; } \\
\text { Olumuyiwa, } 2012\end{array}$ \\
\hline Bank Size (SIZE) & Log of Total Asset & $\begin{array}{l}\text { Amidu, 2014, Costant \& } \\
\text { Ngomsi (2012), Chernykh \& } \\
\text { Theodossiou (2011) }\end{array}$ \\
\hline $\begin{array}{l}\text { Volume of } \quad \text { Deposits } \\
\text { (DEPO) }\end{array}$ & Total Depo & $\begin{array}{l}\text { Qudah, 2017; Moussa, 2016; } \\
\text { Mansour, 2017; Rabab'ah, } \\
\text { 2015, Abdul Adzis, 2018) }\end{array}$ \\
\hline Inflation (INF) & Consumer & $\begin{array}{l}\text { Rabab'ah (2015) and Mansour } \\
\text { (2017) }\end{array}$ \\
\hline $\begin{array}{l}\text { Gross Domestic Product } \\
\text { (GDP) }\end{array}$ & Annual Real Growth Rate & $\begin{array}{l}\text { Moussa, 2016; Amidu, 2014; } \\
\text { Costant \& Ngomsi, 2012; } \\
\text { Rabab'ah, } 2015\end{array}$ \\
\hline
\end{tabular}




\section{Model Estimation}

The empirical model (1) is estimated to determine the size of the impact of bank factors and economic indicators on bank lending. To evaluate the major variables affecting bank lending, multiple regressions using Pooled Ordinary Least Square (POLS) are tested. For the measurement of bank lending, we utilize total loan and advances, as described in Abdul Adzis et al. 2018; Ladime 2013; Ayieyo, 2016; Olumuyiwa, 2012. The following is the estimation model framework for bank lending:

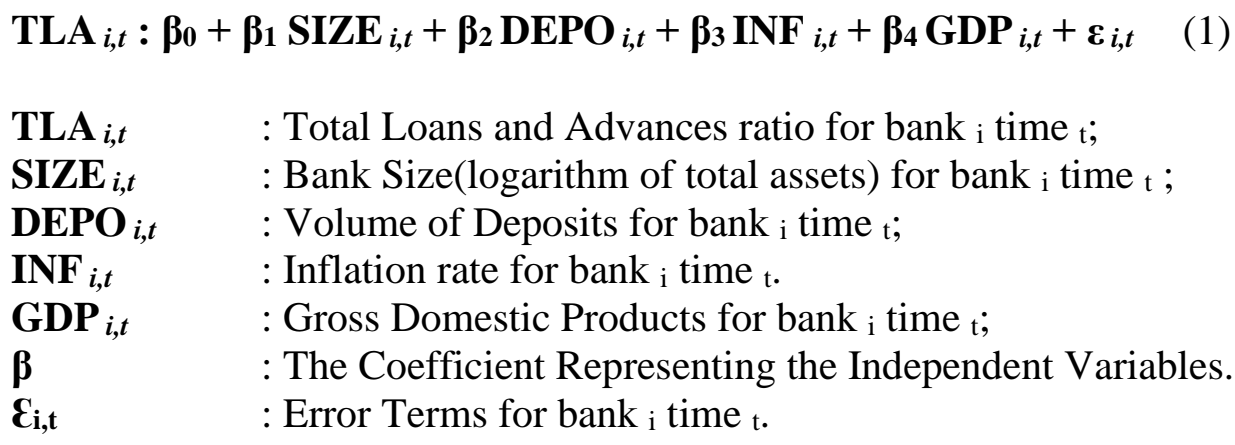

\begin{tabular}{|c|c|c|}
\hline Variable (Symbol) & $\begin{array}{l}\text { Expected } \\
\text { Sign }\end{array}$ & Empirical Evidence \\
\hline Bank Size (SIZE) & + & $\begin{array}{l}\text { Mansour (2017); Chernykh and } \\
\text { Theodossiou (2011); Costant \& Ngomsi } \\
\text { (2012); Abdul Adzis (2018); Zulkhibri } \\
\text { (2018); Rabab'ah (2015). }\end{array}$ \\
\hline Volume of Deposits (DEPO) & + & $\begin{array}{l}\text { Abdul Adzis (2018); Mukhanyi (2016); } \\
\text { Sarath \& Pham (2015); Amano (2014); } \\
\text { Qudah (2017) }\end{array}$ \\
\hline Inflation (INF) & - & $\begin{array}{l}\text { Sharma and Gounder (2012); Ladime } \\
\text { (2013); Sarath \& Pham (2015); Vo (2018); } \\
\text { Zulkhibri (2018) }\end{array}$ \\
\hline Gross Domestic Product (GDP) & + & $\begin{array}{l}\text { Abdul Adzis (2018); Mansour (2017); Vo } \\
\text { (2018); Mukhanyi (2016); Moussa (2016); } \\
\text { Malede (2014); Rabab'ah (2015); Sarath \& } \\
\text { Pham (2015) }\end{array}$ \\
\hline
\end{tabular}

\section{Expected Sign}

Table 2 shows the expected sign and the empirical evidence depicted from literature reviews. Thus, we expect Size of the banks (SIZE), Volume of Deposits (DEPO) and Gross Domestic Product (GDP) to be positive. Meanwhile, Inflation (INF) to be negative. The result might be different from the expected result because of different data set, scope, and methods.

\section{Table 2: Expected Sign}




\section{Empirical Results}

\section{Descriptive Statistics}

Table 3: Descriptive Statistics

\begin{tabular}{llllll}
\hline & TLA & DEPO & GDP & INF & SIZE \\
\hline Mean & 53.64583 & 75.06241 & 314745.2 & 2.327089 & 127889.5 \\
Min & 0.1187936 & 0.3289231 & 258647 & 1 & 122.217 \\
Max & 88.0722 & 95.26164 & 358579 & 3.9 & 2077758 \\
Std Dev. & 20.85485 & 17.7791 & 0.0851392 & 0.8527165 & 334073 \\
CV & 0.3887528 & 0.2368569 & 26797.16 & 0.3664305 & 2.612199 \\
\hline
\end{tabular}

Notes: There are five variables with the total of 347 observations. The dependent variable is Total Loan and Advances (TLA). Meanwhile, the independent variables are defined as follow: Volume of Deposits (DEPO), Gross of Domestic Product (GDP), Inflation Rate (INF), and lastly Total Assets (SIZE).

Table 3 shows the mean value or average of the commercial and Islamic bank lending (TLA) ratio is 53.65 percent. During the study period from 2010 to 2018, commercial and Islamic banks in Malaysia allocated an average of 53.65 percent of their assets to issue loans to the public. The minimum bank lending ratio for commercial and Islamic banks in 2018 is 0.11 percent. The volume of deposits held by commercial and Islamic banks ranges from 5 to 95.26 percent of total assets. One of the Islamic banks received the most deposits from its customers, totaling for 95.26 percent of its total assets.

\section{Correlation Analysis}

Table 4: Correlation Matrix

\begin{tabular}{llllll}
\hline & TLA & DEPO & SIZE & GDP & INF \\
\hline TLA & 1.0000 & & & & \\
DEPO & 0.5077 & 1.0000 & & & \\
SIZE & 0.3287 & 0.1619 & 1.0000 & & \\
GDP & 0.0816 & -0.0605 & 0.0780 & 1.0000 & \\
INF & -0.0211 & 0.0124 & -0.0154 & 0.0044 & 1.0000 \\
\hline
\end{tabular}

Notes: There are five variables with the total of 347 observations. The dependent variable is Total Loan and Advances (TLA). Meanwhile, the independent variables are defined as follow: Volume of Deposits (DEPO), Gross of Domestic Product (GDP), Inflation Rate (INF), and lastly Total Assets (SIZE).

Table 4 illustrates that the largest influences on bank lending are the volume of deposits (DEPO) and the size of the bank (SIZE). Similarly, both independent variables are related to bank lending in a positive way. As the impact of both declines, so will the impact of bank lending. Inflation is adversely connected with total loan and advance ratio, but GDP is positively correlated with bank lending. 
Volume 3 Issue 8 (September 2021) PP. 65-75 DOI 10.35631/AIJBAF.38006

Table 5: Pooled Ordinary Least Square (POLS) Regression

\begin{tabular}{lllllll}
\hline TLA & Coef & Std Error & $\mathbf{t}$ & $\mathbf{P}>|\mathbf{t}|$ & \multicolumn{2}{c}{ [ 95\% Conf. Interval ] } \\
\hline DEPO & 0.5565587 & 0.0528072 & 10.54 & $0.0000 * * *$ & 0.4526909 & 0.6604265 \\
GDP & 21.78343 & 10.63284 & 2.05 & $0.041 * *$ & 0.8694393 & 42.69742 \\
INF & -0.1058961 & 1.104704 & -0.10 & 0.924 & -2.278766 & 2.066974 \\
SIZE & 2.944872 & 0.5399443 & 5.45 & $0.000 * * *$ & 1.882842 & 4.006901 \\
\hline
\end{tabular}

Notes: There are five variables with the total of 347 observations. The dependent variable is Total Loan and Advances (TLA). Meanwhile, the independent variables are defined as follow: Volume of Deposits (DEPO), Gross of Domestic Product (GDP), Inflation Rate (INF), and lastly Total Assets (SIZE). ***Significant at 1\%, ** Significant at $5 \%, *$ Significant at $10 \%$

Table 5 demonstrates that bank size is significant at $1 \%$ and that there is a positive link between bank size, as measured by the logarithm of total assets, and total loan and advance ratio. The reported similar with those of Mansour (2017), Chernykh and Theodossiou (2011), Costant \& Ngomsi (2012), Abdul Adzis (2018), Zulkhibri (2018), and Rabab'ah (2018). (2015). We concur with Zulkhibri (2018), who stated that a bank's size is a significant component in its financing since it allows the bank to reduce costs. Greater banks, according to Abdul Adzis (2018), are more diversified, have larger pools of cash accessible, have access to larger and more creditworthy corporate clients, and have more resources for the development of advanced credit risk management and evaluation systems.

According to Ahmad and Ahmad (2004), larger banks are able to reduce costs because they have enough resources and are able to diversify their asset portfolio efficiently, which reduces credit risks, whereas smaller banks are more likely to be exposed to higher lending risks because they lack the resources to diversify their asset portfolio. Smaller banks, according to Rahman and Shahimi (2010), diversify their portfolios by investing in high-yielding assets. As a result, smaller banks provide less loans to the general population since they are more concerned with return on investment than with credit concerns. To summarise, it is undeniable that larger banks will grant larger loans than smaller banks. The reason for this is because larger banks have the resources to diversify their holdings. As a result, larger banks can invest while also making loans, so reducing risk. Larger banks can save costs in the long run.

In Malaysia, the level of deposits appears to be a significant factor influencing bank lending. We can see that the deposit volume is similarly significant at 1 percent, implying a positive association with bank lending. This finding is comparable to that of Abdul Adzis (2018), who discovered that total bank deposits have a favorable impact on bank lending behaviour. It is reasonable to assume that banks with greater ability to acquire more deposits from their clients will have greater power to grant loans to the general population. This is due to the fact that banks rely on deposits to make loans.

The table also discloses that the gross domestic product (GDP) is significant at 5 percent in affecting the bank lending behavior. It also suggested that GDP and the total loan and advances ratio have a positive link. The findings support Abdul Adzis's (2018) conclusion that as the economy grows, so will loan demand from the public, providing more chances for banks to 
Volume 3 Issue 8 (September 2021) PP. 65-75 DOI 10.35631/AIJBAF.38006

give loans to the general public, resulting in an increase in bank lending. The findings are also in line with those of Vo (2018) and Sarath and Pham (2015), who found that as GDP rises, bank lending rises as well. The fact that the majority of private bank customers are small and medium businesses, which are more flexible than huge corporations, supports this. As a result, the demand functions of private banks may be more sensitive to output growth as well as more interest elastic.

These two characteristics of the demand function would lead private banks to be responsive to the economic growth rate. Furthermore, according to Mansour (2017), gross domestic product has a considerable impact on bank lending. Furthermore, an increase in economic growth is linked to an increase in economic activity. Furthermore, while GDP growth coefficients are generally positive, the magnitudes and statistical significance of major banks are greater (Kim \& Wook, 2017).

\section{Conclusion}

This research adds to the literature by examining the factors that influence bank lending behaviour in Malaysian's dual banking system. As a measure of bank lending, we utilise the total loan and advances ratio. We investigate how bank size, as measured by the logarithm of total assets, and deposit volume, as measured by the ratio of total deposits to total assets, are connected to bank lending behaviour. We also performed a multiple regression analysis to see which variables have the most impact on modifying bank lending behaviour. Two economic indices, namely gross domestic product and inflation, were also included in this analysis. The findings demonstrate that bank size and deposit volume are positively related to bank lending. The more the bank's assets are, the more the loan it can give to its consumers. Larger banks, in particular, have the resources to diversify their holdings. As a result, larger banks can invest while also disbursing loans, so reducing risk. Larger banks are able to save costs in the long run.

In Malaysia, the level of deposits found to be a key influence in influencing bank lending behaviour. When the volume of deposits rises, commercial and Islamic banks in Malaysia will expand their lending. This is because banks rely entirely on the money deposited by customers. When individuals deposit money in banks, the banks have the resources to make loans. When banks get a large amount of deposits, they are more inclined to offer out more loans because the interest rate contained in the loan represents the banks' profit. Furthermore, banks with greater ability to lure more consumers to deposit money have a significant advantage because they can hand out more loans and reserve more funds to fulfil withdrawals in the end. Finally, the gross domestic product, which is one of the economic variables, has a substantial impact on the total loan and advance of the bank in Malaysia. It illustrates that GDP and bank lending have a favourable relationship. The bank will choose to give out more loans as the economy grows. This is because a high GDP will open up more job opportunities in the market, and firms will need more money to expand. They will then demand a loan, which will increase the demand for borrowing. As a result, the bank will be able to receive more money from the loan's interest income. As a result, the bigger the GDP, the higher the commercial and Islamic banks' bank loans will be. 


\section{References}

Abdul Adzis, A., Sheng, L. E., \& Abu Bakar, J. (2018). Bank lending determinants: Evidence from Malaysia commercial banks. Journal of Banking and Finance Management, 1(3), 36-48.

Abdul Karim, Z., Azman-Saini, W. N. W., \& Abdul Karim, B. (2011). Bank lending channel of monetary policy: Dynamic panel data study of Malaysia. Journal of Asia-Pacific Business, 12(3), 225-243.

Ahmad, A., Humayoun, A. A., \& ul Hassan, U. (2010). An analysis of functions performed by Islamic bank: a case of Pakistan. European Journal of Social Sciences, 17(1), 7-11.

Amidu, M. (2014). What influences banks' lending in sub-Saharan Africa? Journal of Emerging Market Finance, 13(1), 1-42.

Ayieyo, J. O. (2016). Determinants of lending behaviour in selected commercial banks in Kenya. International Journal of Economics, Commerce and Management, 14(9), 767782.

Alkhazaleh, A. M. K. (2017). Factors may drive the commercial banks lending: evidence from Jordan. Banks and Bank Systems, 12(2), 31.

Bank Negara Malaysia. (2015). Financial Stability and Payment System Report 2014. Kuala Lumpur Bank Negara Malaysia

Cole, R. A., Goldberg, L. G., \& White, L. J. (2004). Cookie cutter vs. character: The microstructure of small business lending by large and small banks. Journal of financial and quantitative analysis, 39(2), 227-251.

Chernykh, L., \& Theodossiou, A. K. (2011). Determinants of bank long-term lending behavior: Evidence from Russia. Multinational Finance Journal, 15(3/4), 193-216.

Constant, F. D., \& Ngomsi, A. (2012). Determinants of bank long-term lending behavior in the Central African Economic and Monetary Community (CEMAC). Review of Economics \& Finance, 2(5), 107-114.

Ladime, J., Sarpong-Kumankoma, E., \& Osei, K. A. (2013). Determinants of bank lending behaviour in Ghana. Journal of Economics and Sustainable Development, 4(17), 4247.

Malede, M. (2014). Determinants of commercial banks lending: evidence from Ethiopian commercial banks. European Journal of Business and Management, 6(20), 109-117.

Matousek, R., \& Solomon, H. (2018). Bank lending channel and monetary policy in Nigeria. Research in International Business and Finance, 45, 467-474.

Moussa, M. A. B. (2015). The determinants of bank liquidity: Case of Tunisia. International Journal of Economics and Financial Issues, 5(1), 249.

Mukhanyi, M. (2016). Determinants of lending behaviour of commercial banks in Kenya (Doctoral dissertation, University of Nairobi).

Olokoyo, F. O. (2011). Determinants of commercial banks' lending behavior in Nigeria. International journal of financial research, 2(2), 61-72.

Olumuyiwa, O. S., Oluwatosin, O. A. and Chukwuemeka, O. E. (2012). Determinants of Lending Behaviour of Commercial Banks: Evidence from Nigeria, a Co-Integration Analysis. Journal of Humanities and Social Science, 5(5), 71-80.

Qudah, Y. (2017). Determinants of domestic bank lending behavior evidence of Jordan (Master's thesis, Eastern Mediterranean University (EMU)-Doğu Akdeniz Üniversitesi (DAÜ)).

Rabab'ah, M. (2015). Factors affecting the bank credit: An empirical study on the Jordanian commercial banks. International journal of Economics and Finance, 7(5), 166-178. 
Volume 3 Issue 8 (September 2021) PP. 65-75 DOI 10.35631/AIJBAF.38006

Sarath, D. (2015). The determinants of Vietnamese banks' lending behavior: A theoretical model and empirical evidence. Journal of Economic Studies.

Tabila, N. E. (2016). Determinants of Commercial Banks' Lending Behavior in South Africa (Master's thesis, Eastern Mediterranean University (EMU)-Doğu Akdeniz Üniversitesi (DAÜ)).

Waemustafa, W., \& Sukri, S. (2015). Bank specific and macroeconomics dynamic determinants of credit risk in Islamic banks and conventional banks. International Journal of Economics and Financial Issues, 5(2), 476-481.

Vo, X. V. (2018). Bank lending behavior in emerging markets. Finance Research Letters, 27, 129-134.

Zulkhibri, M. (2018). The impact of monetary policy on Islamic bank financing: bank-level evidence from Malaysia. Journal of Economics, Finance and Administrative Science, 23(2), 306-322. 